Hoyt, R. E., Morrison, L. M., and Levine, M. G. (1961). The nature of the hemagglutinating agent noted in the blood serum of patients with viral hepatitis. Fournal of Laboratory and Clinical Medicine, 58, 104.

Morrison, L. M., and Hoyt, R. E. (1957). Hemagglutination reactions noted in viral hepatitis. Fournal of Laboratory and Clinical Medicine, 49, 774.

Morrison, L. M., Hoyt, R. E., Levine, M., Rosenthal, M., Holeman, R. L., and Stevens, M. R. (1960). Further experience with hemagglutination in viral hepatitis. American fournal of Gastroenterology, 33, 461.

Morrison, L. M., Rosenthal, M., Holeman, R., and Stevens, M. (1961). The relationship of viral hepatitis to cirrhosis of the liver. American fournal of Gastroenterology, 35, 371.

Rubin, B. A., Kemp, H. A., and Bennett, H. D. (1957). Mechanism of agglutination of Macaca rhesus erythrocytes by human hepatitis serum. Science, 126, 1117.

Stokes, J. F., Jr., Wolman, I. J., Blanchard, M. C., and Farquhar, J. D., (1951). Viral hepatitis in the newborn: clinical features, epidemiology, and pathology. (Abstr.) American fournal of Diseases of Children, 82, 213.

Leila Ramakumar and S. M. Gupta

Department of Paediatrics, Government Medical College, Patiala, India.

\section{Insulin Studies in Temporary Neonatal Hyperglycaemia}

Very few insulin studies have been performed in infants with temporary neonatal hyperglycaemia. Lewis and Mortimer (1964) used the rat diaphragm method and were unable to demonstrate any insulin-like activity in a patient before treatment was started. Ferguson (1967) carried out plasma insulin studies from birth in one such infant. The immunoreactive insulin levels were considered to be at the upper limit of normal in that infant. Unfortunately, no further insulin studies were possible, after the patient recovered from the diabetic state, as he died shortly afterwards in renal failure as a result of polycystic disease of the kidneys.

Gentz (1969), also using the radioimmunoassay technique, reported levels of 6 and $17 \mu \mathrm{U} / \mathrm{ml}$ plasma immunoreactive insulin before treatment in 2 affected infants. Both these infants had developed symptomatic hypoglycaemia before the development of the hyperglycaemia.

A case is reported here where plasma immunoreactive insulin studies were carried out before treatment was started, and repeated again at the age of 1 month, and at the age of 4 months.

\section{Case History}

The patient, a female infant weighing $1890 \mathrm{~g}$, was born by spontaneous vaginal delivery in October 1969, three weeks before the expected date of delivery. The mother was 30 years old, in good health, and this was her ninth pregnancy. She had four children who were alive and well. Four other pregnancies had aborted spontaneously during the first 16 weeks of pregnancy. During this pregnancy she had been well apart from some vaginal bleeding at the eighth week. The infant gasped and cried immediately at birth, and only required mucus extraction and facial oxygen for resuscitation. The Apgar score was 7 at 2 minutes. She showed the appearances of placental insufficiency, with wrinkled skin and lack of subcutaneous fat. During the first 2 days of life there was some vomiting, but artificial feeding with Ostermilk No. 1 was quickly established, and by the eighth day she had almost regained her birthweight.

On the eighth day of life generalized twitching of both arms and legs was noted. A provisional diagnosis of tetany was confirmed, the serum calcium being 3.0 $\mathrm{mEq} / \mathrm{l}$., phosphate $10.5 \mathrm{mg} / 100 \mathrm{ml}$, and the alkaline phosphatase $14.5 \mathrm{KA}$ units $/ 100 \mathrm{ml}$. She was treated with calcium chloride $300 \mathrm{mg}$ orally every 6 hours for 3 days and the convulsions ceased. Feeding continued satisfactorily during this time but she was noted to be losing weight. On the eleventh day there was a rapid deterioration in her general condition, the respiration was acidotic in type, and severe acidosis was confirmed biochemically. The $p \mathrm{H}$ was $6.87, \mathrm{PcO}_{2} 22.0 \mathrm{~mm}$ $\mathrm{Hg}$, standard bicarbonate less than $5.0 \mathrm{mEq} / \mathrm{l}$, and the base deficit $22.0 \mathrm{mEq} / 1$. Convulsive twitching again developed on this day. The metabolic acidosis was regarded as due, at least in part, to over dosage with calcium chloride. Her general condition rapidly improved over the next few hours as the acidosis was corrected with intravenous $8.4 \%$ sodium bicarbonate, but she continued to have convulsive twitching for another three days in spite of intramuscular phenobarbitone $15 \mathrm{mg}$ 6-hourly. Twitching finally ceased in the fourteenth day of life. On the thirteenth day of life, however: she was found to have a marked glycosuria, and the true blood glucose was $350 \mathrm{mg} / 100 \mathrm{ml}$. There was no ketonuria, but a trace of albumin was present in the urine. A urine chromatogram showed only glucose to be present. After a 4-hour fast a glucose tolerance test with insulin studies was performed after the oral administration of $5 \mathrm{~g}$ glucose. The glucose tolerance test was diabetic in type (Table I). She was given 5 units of soluble insulin, twice that day, which promptly controlled the hyperglycaemia, and there was marked improvement in her general condition. The following day, 4 units of soluble insulin were required on two occasions. On the third day of treatment only 2 units of soluble insulin were required, and 1 unit of soluble insulin was given 3 days later. After this time no further insulin was required. On the seventeenth day of life the urine was free of reducing substances, the fasting true blood glucose was $57 \mathrm{mg} / 100 \mathrm{ml}$, and a transfusion of $75 \mathrm{ml}$ whole blood was given with further improvement in her condition. Over the next few days good progress was maintained and an excellent weight gain was established. The urine remained free of reducing substances, and on the twenty-sixth day of life a fasting true blood glucose after a $3 \frac{1}{2}$-hour fast was $54 \mathrm{mg} / 100 \mathrm{ml}$, 
and the immunoreactive insulin was $7 \mu \mathrm{U} / \mathrm{ml}$. On the thirty-second day of life an oral glucose tolerance test with insulin studies was repeated (Table I).

At the age of 4 months an intravenous glucose tolerance test, and an intravenous tolbutamide test were both carried out, with further insulin studies (Table II).

\section{TABLE I}

Glucose Tolerance Test at Onset of Hyperglycaemia, with Plasma Immunoreactive Insulin Levels

\begin{tabular}{|c|c|c|c|c|c|}
\hline \multicolumn{4}{|c|}{ Time after $5 \mathrm{~g}$ glucose } & Blood Glucose & Insulin \\
\hline $\begin{array}{c}\text { Age } 13 \text { days } \\
\text { Fasting } \\
\frac{1}{2} \text { hour } \\
1 \text { hour } \\
1 \frac{1}{2} \text { hours } \\
2 \text { hours }\end{array}$ & $\begin{array}{l}\cdots \\
\cdots \\
\cdots \\
\cdots\end{array}$ & $\begin{array}{l}\cdots \\
\cdots \\
\cdots \\
\cdots\end{array}$ & $\begin{array}{l}\cdots \\
\cdots \\
\cdots \\
\cdots\end{array}$ & $\begin{array}{l}370 \\
384 \\
376 \\
440 \\
428\end{array}$ & $\begin{array}{r}16 \\
184 \\
170 \\
121 \\
67\end{array}$ \\
\hline $\begin{array}{l}\text { Age } 1 \text { month } \\
\text { Fasting } \\
\frac{1}{2} \text { hour } \\
1 \text { hour } \\
1 \frac{1}{2} \text { hours } \\
2 \text { hours } \\
3 \text { hours }\end{array}$ & $\begin{array}{l}\ldots \\
\ldots \\
\ldots \\
\ldots \\
\ldots\end{array}$ & $\begin{array}{l}. \\
\ldots \\
\ldots \\
\ldots \\
\ldots\end{array}$ & $\begin{array}{l}\ldots \\
\ldots \\
\ldots \\
\cdots \\
\ldots\end{array}$ & $\begin{array}{r}80 \\
109 \\
130 \\
101 \\
85 \\
75\end{array}$ & $\begin{array}{r}7 \\
9 \\
57 \\
34 \\
21 \\
14\end{array}$ \\
\hline
\end{tabular}

\section{TABLE II}

Intravenous Tolbutamide Test at Age of 4 Months

\begin{tabular}{|c|c|c|c|c|c|}
\hline \multicolumn{4}{|c|}{ Time (min) after Tolbutamide } & $\begin{array}{l}\text { Blood Glucose } \\
(\mathrm{mg} / 100 \mathrm{ml})\end{array}$ & $\underset{(\mu \mathrm{U} / \mathrm{ml})}{\text { Insulin }}$ \\
\hline \multicolumn{4}{|c|}{$20 \mathrm{mg} / \mathrm{kg}$ body weight tolbutamide } & & \\
\hline Fasting & .. & . & . & 54 & 7 \\
\hline 20 & .. & .. & .. & 56 & 8 \\
\hline 30 & .. & .. & . & 50 & 13 \\
\hline 60 & .. & .. & . & 31 & 6 \\
\hline 90 & . & .. & . & 42 & 3 \\
\hline 120 & . & . & $\cdots$ & 48 & 7 \\
\hline \multicolumn{4}{|c|}{$1 \mathrm{~g} / \mathrm{kg}$ body weight glucose } & & \\
\hline Fasting & .. & $\ldots$ & . & 62 & 7 \\
\hline 10 & $\ldots$ & .. & . & 284 & 13 \\
\hline 20 & .. & . & .. & 254 & 12 \\
\hline 30 & $\cdots$ & $\ddot{0}$ & $\cdots$ & 224 & 10 \\
\hline 60 & .. & .. & .. & 154 & 9 \\
\hline
\end{tabular}

$\mathrm{kG}$ (rate of disappearance of glucose from the blood) value $\mathbf{1} \cdot \mathbf{2}$.

The infant is now microcephalic with spastic tetraplegia. It is noteworthy that 3 out of the 4 cases previously described by Hutchison, Keay, and Kerr (1962) were found to be mentally retarded but not spastic when examined later. While 2 of their patients had had hypoglycaemic episodes during treatment these did not occur in the present case.

\section{Discussion}

In the initial glucose tolerance test, there was a very striking rise in the insulin levels as a result of the oral dose of glucose. Even 2 hours later, the level was still 4 times greater than the fasting level. At the same time the corresponding blood glucose levels were continuously rising. This suggests that, though the insulin present in the infant's plasma was immunoreactive, functionally it was inactive. On the other hand, the effect of the exogenous insulin in bringing the diabetic state under control was very striking in this infant, suggesting that the tissues themselves were very sensitive to the effect of insulin. This phenomenon has already been well documented in similar cases (Hutchison, 1967; Ferguson and Milner, 1970). At the age of 1 month when the glucose tolerance test repeated, the blood glucose levels showed an entirely normal configuration, but once again, though the fasting insulin level was well within the normal range, there still appeared to be an exaggeration in the insulin response. At the age of 4 months, both the intravenous tolbutamide and the intravenous glucose tolerance tests were within normal limits. The $\mathrm{kG}$ value of $1 \cdot 2$ was within the normal range for that age group, and the insulin levels showed the expected changes.

Ferguson and Milner (1970) suggested that transient neonatal diabetes might be due to delay in the maturation of the fetal $\beta$-cells, and that the delay might be due to a combination of maternal and placental factors. Steiner and his colleagues (1968) have shown that the purified fractions of proinsulin all react with antisera to insulin, but in the purified intact form, proinsulin has very low biological activity. Rastogi, Letarte, and Fraser (1970) showed that human fetal insulin had similar properties, but after partial tryptic digestion its biological activity was increased by over $800 \%$. It is suggested that in this case the pancreas was unable to produce biologically active insulin, but in response to a glucose load was able to produce a biologically inactive form of insulin which reacted in the radioimmunoassay. It will only be after more such cases have been studied in this way, and facilities for measuring proinsulin as well as insulin are more fully developed, that the exact roles played by these different forms of insulin will be understood.

\section{Summary}

Very high levels of immunoreactive insulin were found in a child with temporary neonatal hyperglycaemia during the course of illness, but they later returned to normal. It is suggested that high levels of immunoreactive insulin in the presence of obvious hyperglycaemia may be due to the production of a biologically inactive form of insulin. 
I thank Professor J. H. Hutchinson and Dr. Margaret $M$. Kerr for advice and encouragement during the preparation of this paper.

\section{REFERENCES}

Ferguson, A. W., and Milner, R. D. G. (1970). Transient neonatal diabetes mellitus in sibs. Archives of Disease in Childhood, $45,80$.

Ferguson, I. C. (1967). Neonatal hyperglycaemia; case report with plasma insulin studies. Archives of Disease in Childhood, 42, 509.

Gentz, J. (1969). Transient diabetes of the newborn. Acta Paediatrica, 58, 655.

Hutchison, J. H. (1967). Practical Paediatric Problems, 2nd ed., p. 376. Lloyd-Luke, London.

Hutchison, J. H., Keay, A. J., and Kerr, M. M. (1962). Congenital temporary diabetes mellitus. British Medical fournal, 2, 436.

Lewis, S. R., and Mortimer, P. E. (1964). Idiopathic neonatal hyperglycaemia. Archives of Disease in Childhood, 39, 618.

Rastogi, G. K., Letarte, J., and Fraser, T. R. (1970). Proinsulin content of pancreas in human fetuses of healthy mothers. Lancet, 1, 7.

Steiner, D. F., Hallund, O., Rubenstein, A., Cho, S., and Bayliss, C. (1968). Isolation and properties of proinsulin, intermediate forms, and other minor components from crystalline bovine insulin. Diabetes, 17, 725.

Marthe A. Le Dune

University Department of Child Health and the Queen Mother's Hospital, Glasgow.

Correspondence to Dr. M. A. Le Dune, Paediatric Department, Stobhill General Hospital, Glasgow N.1.

\section{Cor Pulmonale in Crouzon's Disease}

Cor pulmonale resulting from upper airway obstruction secondary to hypertrophy of the tonsils and adenoids has now been well documented (Macartney, Panday, and Scott, 1969; Menashe, Farrehi, and Miller, 1965; Ainger, 1968; Levy et al., 1967; Cox et al., 1965). The features of this syndrome are (i) noisy stertorous respiration and stridor in the supine position, (ii) somnolence, (iii) pulmonary hypertension, (iv) right heart failure, (v) electrocardiographic changes of right atrial and right ventricular hypertrophy and strain, (vi) arterial hypoxia and hypercapnia, and (vii) radiographic appearances of cardiomegaly, dilatation of the pulmonary artery, and often pulmonary oedema.

Cox et al. (1965) also described an infant with laryngotracheomalacia who went on to develop cor pulmonale. We describe a further case of cor pulmonale secondary to chronic nasopharyngeal obstruction, this time in a patient with Crouzon's disease. It is felt that the abnormal facial bony development in Crouzon's disease, with consequent narrow nasopharyngeal and oropharyngeal airway, has contributed to the nasopharyngeal obstruction in this patient.

\section{Case Report}

This 3-year-old child presented with a 3-day history of ankle oedema. She had been diagnosed as having Crouzon's disease at the age of 8 weeks when she was referred for paediatric opinion, because of unusual facies.

Bilateral craniectomy was performed at the age of 7 months for craniostenosis. At the age of 2 years she was referred to an ear, nose, and throat surgeon because of noisy breathing. The parents were informed that the child had narrow air passages and that no further treatment was possible.

Neither of the parents was clinically affected by Crouzon's disease, but a paternal uncle and the paternal grandmother were both affected.

On examination on admission she was in right heart failure with central cyanosis, peripheral pitting oedema, tachycardia, tachypnoea, hepatomegaly, and noisy respiration. Chest $x$-ray showed gross cardiomegaly with early pulmonary oedema. The electrocardiogram (Fig. 1) showed an axis of +150 with evidence of right atrial and right ventricular hypertrophy. Blood gases breathing oxygen, soon after admission, showed $\mathrm{P}_{\mathrm{a}} \mathrm{O}_{2}$ $70 \mathrm{~mm} \mathrm{Hg}, \mathrm{P}_{\mathrm{aCO}} 98 \mathrm{~mm} \mathrm{Hg}$, and $\mathrm{HCO}_{3}$ of $36.5 \mathrm{mEq} / 1$. She was treated with digoxin, frusemide, and oxygen with good improvement. An oral airway was needed to maintain a good colour. Cardiac catheter studies were performed to exclude a cardiomyopathy or intracardiac shunt. These investigations, which unfortunately were limited because of a cardiac arrest, showed pulmonary hypertension with a pulmonary artery pressure of $75 / 50 \mathrm{~mm} \mathrm{Hg}$, but with considerable decrease in pressure on inspiration (Fig. 2). Arterial gases at rest, breathing room air, showed hypoxia and hypercapnia with $\mathrm{P}_{\mathrm{a}} \mathrm{O}_{2} 31 \mathrm{~mm} \mathrm{Hg}$ and $\mathrm{P}_{\mathrm{a}} \mathrm{CO}_{2}$ of $66 \mathrm{~mm} \mathrm{Hg}$. After intubation and inflation with $100 \%$ oxygen, after cardiac arrest, the $\mathrm{P}_{\mathrm{a}} \mathrm{O}_{2}$ improved to $425 \mathrm{~mm} \mathrm{Hg}$ and the $\mathrm{P}_{\mathrm{a}} \mathrm{CO}_{2}$ came down to $45 \mathrm{~mm} \mathrm{Hg}$. These findings supported the diagnosis of cor pulmonale.

The patient improved considerably on medical treatment, though she still had noisy respiration and respiratory obstruction when sleeping.

She had several episodes of upper respiratory tract infection, associated with croup between discharge from hospital in June and readmission in September for adenotonsillectomy. At operation she had moderately enlarged tonsils and small adenoids. The ear, nose, and throat surgeon and anaesthetist commented on the very small postnasal space.

Postoperatively she no longer had noisy respiration, and a femoral vein puncture a month later showed a normal $\mathrm{PCO}_{2}$.

\section{Comment}

Crouzon in 1912 was the first to describe the features of the syndrome that now bears his name 